\title{
Rho GTPase-Activating Protein 11B
}

National Cancer Institute

\section{Source}

National Cancer Institute. Rho GTPase-Activating Protein 11B. NCI Thesaurus. Code C125467.

Rho GT Pase-activating protein 11B (267 aa, $~ 30 \mathrm{kDa}$ ) is encoded by the human ARHGAP11B gene. This protein is involved in corticogenesis. 